\title{
POPULATION DYNAMICS OF THE SYCAMORE LACE BUG, CORYTHUCHA CILIATA (SAY) (HETEROPTERA: TINGIDAE) IN HUNGARY
}

\author{
ÖSZI, B. - LADÁNYI, M. - HUFNAGEL, L.* \\ *e-mail: levente.hufnagel@uni-corvinus.hu \\ Corvinus University of Budapest, Department of Mathematics and Informatics, \\ H-1118 Budapest, Villányi út 29-43, Hungary \\ *Corresponding author. \\ (Received $2^{\text {nd }}$ Jan 2004; accepted $4^{\text {th }}$ August 2005)
}

\begin{abstract}
Based on the observation of more than 10000 leaves of plane trees, four populations of Corythucha ciliata (Say, 1832) (Heteroptera: Tingidae) are investigated. After having introduced some parameters derived from the data, we draw spatial-temporal patterns and describe the seasonal population dynamics of Corythucha ciliata. Amongst others, the temporal change of the density of population, the state plane of larvae-adults, the inclination to accumulate, and the intraspecific competition are examined. Population and biomass dynamics is characterized for populations with and without limited nutrient source in case of different weather circumstances and effects.
\end{abstract}

Keywords. population dynamics, spatial-temporal patterns, state planes, seasonality, ecology

\section{Introduction and aims}

One of the most important practical questions of plant protection is, how to choose the most suitable date of a plant protection method, that is to say, how to define the date, when the method the most effective is. The effectiveness of a method depends, above all, on the phenology of the pests, more exactly, on the number of the individuals at a critical point of their phenology.

The time and the way of the process of all the reproduction events are closely connected to the external factors that regulate the population dynamics [8].

To recognize these important factors, spatio-temporal variables are needed to be explored and their patterns are needed to be drawn.

With the help of spatio-temporal patterns, the processes within a population can better be recognized. To evaluate correctly the observed ecological parameters, it would be very useful to apply a population-dynamical model, with the help of which, for a given series of ecological events, the consequent changes in the population can be forecasted. This method can result a precision technology.

During our research, we followed the population-dynamical changes of four different populations of the sycamore lace bug, Corythucha ciliata (Say, 1832), with biometrical methods. The spatio-temporal changes of the state were recorded carefully in a way, they can be well evaluated.

After having arranged the data, our first aim was, to draw spatio-temporal patterns for a fixed vegetation period of the populations, and in this way, to gain the seasonalbiomass-dynamic of $C$. ciliata. 
When choosing the species, its following ecological advantages were regarded:

1. it is (practically) monophagous;

2. as it was introduced to Hungary not a long time ago, it has yet practically no natural enemy, which can limit its reproduction;

3 . it can easily be observed;

4. it is one of the most dangerous pets of the trees in the parks of Budapest, so the results can well be applied. [2, 3, 5, 6, 7, 10, 11, 21, 36, 37, 39, 41, 43, 45]

\section{Review of literature}

\section{The way of life of Corythucha ciliata}

The way of life of $C$. ciliata was observed in Hungary for the first time by Jasinka and Bozsits [19]. The adults are wintering under the bark, showing their dorsal side to the trunk. The number of them can reach up to 200 individuals $/ \mathrm{dm}^{2}$. There is no wintering generation under the bark of too young and too old trees. The reason is that there is no rift under the bark of young trees, and there are many other kinds of pests wintering under the bark of old trees.

As the average daily temperature rises above $8{ }^{\circ} \mathrm{C}$ in spring, the adults emerge and start wandering. The wandering can strictly be limited by wet weather. The first eggs are laid around at the beginning of May; the number of production is $80-160$ eggs/female. The swarming starts about at the end of May, the embryonic state of developing lasts three weeks, or so. Around three weeks after the larvae have developed the second egglaying-period starts at about the second half of July with a number of production 80-160 eggs/female. Approximately, in the middle of September, the adults of the second generation emerge, and they start wintering at about the end of October [35].

Vásárhelyi \& Hufnagel [42] have noted the sucking and the mating behaviour of the wintered generation. Moreover, they noticed, that the ratio of males and females is varying cyclically during the vegetation period: it is about $50-50 \%$ in the mating period, and it turns to $25-75 \%$ in the wintering period. The larvae move in the first and second period very slowly, in the third period a little more briskly, in the fourth and fifth period as intensively, as the adults. The ratio of reproduction is quite high: the average is 9 larvae/female that results 8 adults/female. Corythucha ciliata prefers the north side of the tree in winter, and the south side in the vegetation period (See also [26]).

Kükedi \& Pálmai $[24,25]$ observed that after the adults have emerged in spring, too cold weather could make them continue their wintering period (quiescentia). By an examination of the damages they stated, that the individuals are distributed mainly in the lower part of the crown of the tree (see also [45]).

Kükedi \& Pálmai $[24,25]$ noticed that the generations of the pests and the weather conditions correlate strongly. The point of the time the larva period starts, the length of a given period, as well as the date of the start of wintering and the mortality in winter are influenced by the temperature.

\section{The natural enemies of Corythucha ciliata}

Balarin \& Maceljski $[5,6]$ have listed the natural enemies of $C$. ciliata. They mention several types of bedbugs and spiders, crickets and locusts [1], viruses, nematodes and spore plants [36]. Balarin \& Maceljski [5,6] have found some fungus species that 
devastate the wintering adults (e.g., Beauberia bassiana cause mortality of $10-15 \%$ of the individuals).

Arzone \& Ozino-Marletto [4] have compared three types of deuteromycete fungi. These were Beauveria bassiana, Vertillium lecanii and Paecilomyces farinosus. They isolated the fungi from the wintered adults with which they infected other C. ciliata larvae and adults in different phenophases. The most virulent was Beauveria bassiana, while the less virulent one was Paecilomyces farinosus.

Driesche [13] advises introducing natural enemies from America.

Tavella \& Arzone [38] have pointed out that, though several predator-nutrient connections have been proved in laboratories, under natural circumstances these predators are playing no limiting role in the reproduction of $C$. ciliata.

\section{The protection against Corythucha ciliata}

Arzone [2] has examined the effect of $C$. ciliata on plane trees. He has shown that as the cytoplasm (mainly the cloroplastices) are sucked, not only the leaf itself, but also the whole tree can die, as a consequence of the insufficient nutrient supply.

Nikusch [34] has warned that besides the fact the C. ciliata can cause great damages, it is also conductive to the infection both of Gnomonia veneta and Ceratocystis fimbriata.

Jasinka \& Bozsits [19] have defined the optimal point of time of forecasting. They established that, in case there are 4 individulas $/ \mathrm{dm}^{2}$ (or more) on the trees at about the high of $180 \mathrm{~cm}$ at the end of May - beginning of April, then, supposed a dry summer is coming, the rate of the infection is expected to be quite high.

Jasinka [18] has pointed out, that it is very important to find out such plant protection technologies that protect the environment, as well. Nevertheless, he emphasized, that $C$. ciliata tolerates the insecticides with phosphorus acid ester ingredient quite well, though this ingredient is belonging to the toxic-category "medium". Moreover, tolerance or resistance can develop against suitable toxic ingredients, too. Using pyrethroids with effective toxic we can make it possible to protect the environment during plant protection.

Wicki [43] has used tree - binding made of jute with success. Worm-belt can, nevertheless, be not applied, as the bugs are moving to have their diapauses by flying and not by creeping.

Mittempergher \& Ferrini [33] have proved that different Italian varieties have different levels of susceptibility to C. ciliata. They have made efforts to select the tolerant and resistant varieties in order to solve the problem of biological protection.

Tremblay [41] has examined three kinds of chemical ways of protection.

With spraying on the leaves, active animals can be killed. During this method, however, pesticides pollute the environment, which is a great disadvantage, especially in towns.

Though treating the trees under their barks is not so harmful, this method is even not so effective.

The most effective and, at the same time, the less polluting method is to inject the insecticide into the transport tissues of the trees. The chemical thus can reach the organism of $C$. ciliata by being sucked. He has noted, however, that this method is also harmful for the trees, as the danger of being infected by another pet becomes higher.

Reiderné \& Ripka [35] recommend a combined technology both with mechanical and chemical treatments. 
Some further results of experiments with different treatments can be found in Kükedi \& Pálmai [24,25], Cziklin [11] and Koletár [21].

\section{Geographical spreading of Corythucha ciliata}

Considering the climate aspects, only, we can state that $C$. ciliata, the original homeland of which is North America, can spread out in the entire area of Europe. However, as it is monophagous, plane tree populations can limit the distribution [17].

Corythucha ciliata is supposed to have been brought into Europe by ships. It was first recorded in Padova, Italy, in 1966. The main stations of its spread are were as follows: Triest, Italy (1968-69), Zagreb, Rijeka, Ljubljana (1972), Istria (1974), South France (1975), Spain (1978), South Austria (1983), Switzerland (1983), the former Czechoslovakian Republic (1986), Bulgaria (1986), Greece (1988). [12, 13, 16, 19, 23 , 27, 28, 29,30,31, 35, 39, 40, 42, 44]

Corythucha ciliata was found in Hungary for the first time in Zákány (county Somogy), in 1976 [19]. In 1985, it was spread all over the country [9], though serious damages were noticed not earlier than in 1989 [42].

\section{The nutrient plant of Corythucha ciliata}

Corythucha ciliata was known as a kind of pest of several series of plane trees even in its original homeland, North America. The larvae are sucking the backside of the leaves in groups. All varieties of the plain genus can be infected, such as Platanus occidentalis, Platanus wrighti and Platanus racemosa in America, as well as Platanus orientalis and Platanus hybrida in Hungary. Though C. ciliata prefers plane trees, it can feed even on Broussonetia papyrifera, Carya spp. and Fraxinus spp., too.

Plane trees, containing the single genus Platanus L., are deciduous and monoecious, living in the northern part of the temperate zone. Plane trees are quite widespread in two great areas, such as from East-Mediterranean to West Himalayas and from Mexico to Canada.

Plane trees were living on the Northern Hemisphere even in Cretaceous period. They were quire widespread in the Miocene (for about 15 million years ago) in the area of the present Hungary. Plane trees of today have the origin of the nurseries of the 19th and 20th centuries [20]. In Hungary, Platanus hybrida (acerifolia) is the most common species, as it is frequently planted along streets and roads as well as in parks.

\section{Materials and methods}

\section{Location and time of the investigation}

Plane tree populations were examined in three areas and during three vegetation periods (Table 1).

Table 1. Location and time of the investigation, the rate of infection

\begin{tabular}{ccc}
\hline location & year & rate of Corythucha ciliata infection \\
\hline Kodály körönd, Budapest & 1989 & high \\
Margit-sziget, Budapest & 1998 & medium \\
HIRP, Budapest & 1998 & high \\
HIRP, Budapest & 1999 & high \\
\hline
\end{tabular}




\section{Kodály körönd, Budapest}

The protected plane trees on Kodály körönd, Budapest, were planted in 1880 [20]. The C. ciliata populations were observed from March to November 1989, one or two times a week. That is to say, data were started to be collected before the leaves were out and the process ended when C. ciliata went to winter.

\section{Margit-sziget (Margaret Island), Budapest}

The plane trees on Margit-sziget, Budapest, were planted by Károly Tost, after the great flood of year 1838. Due to the environmental rules, these trees are healthier, than those ones, staying along the streets [20]. Sampling was made here weekly, or in every second weeks, from 17th May, until the end of September 1998.

\section{HIRP, Budapest (Árpád fejedelem útja)}

The plane trees in front of the Hungarian Institute for Rheumatology and Physiotherapy (HIRP), Budapest, were planted in 1897 [20]. The data were collected during two vegetation periods, namely 1) between 17th June 1998 and the end of September 1998 and 2) between 14th April 1999 and the end of October 1999.

\section{Recorded data}

The dates, the periods, the frequencies, the sample sizes and the recorded parameters of the sampling sites are given on Table 1 and 2. During the sampling the number of the individuals per leaf was recorded for each site and period, nevertheless, in some cases, time to time, further leaves were added to the investigation.

\section{Weather factors}

The daily average temperature, the daily maximum and minimum temperature, the amount of precipitation and the number of sunny ours were recorded. The extreme values are marked on the biomass model.

Table 2. Data of the sampling sites and periods

\begin{tabular}{|c|c|c|c|c|}
\hline & \multicolumn{4}{|c|}{ location } \\
\hline & Kodály körönd & Margit-sziget & HIRP & HIRP \\
\hline year & 1989 & 1998 & 1998 & 1999 \\
\hline period & 17.IV-13.X & 17.V-30.IX & 15.VI-30.IX & 17.IV-30.X \\
\hline frequency & 1-2 times a week & once a week & once a week & once a week \\
\hline (number of & 100 & $68-130$ & $88-169$ & $75-224$ \\
\hline $\begin{array}{l}\text { recorded } \\
\text { parameters }\end{array}$ & $\begin{array}{l}\text { - number of adults } \\
\text { on each leaf } \\
\text { (male/female); } \\
\text { - number of larvae } \\
\text { on each leaf } \\
\text { (phenophases) }\end{array}$ & $\begin{array}{l}\text { - number of adults } \\
\text { on each leaf } \\
\text { (male/female); } \\
\text { - number of larvae } \\
\text { on each leaf } \\
\text { (phenophases) } \\
\text { - size of leaves; } \\
\text { - rate of being } \\
\text { sucked (\%) }\end{array}$ & $\begin{array}{l}\text { - number of adults } \\
\text { on each leaf } \\
\text { (male/female); } \\
\text { - number of larvae } \\
\text { on each leaf } \\
\text { (phenophases); } \\
\text { - size of leaves; } \\
\text { - rate of being } \\
\text { sucked (\%) }\end{array}$ & $\begin{array}{l}\text { - number of adults } \\
\text { on each leaf } \\
\text { (male/female); } \\
\text { - number of larvae } \\
\text { on each leaf } \\
\text { (phenophases); } \\
\text { - size of leaves; } \\
\text { - rate of being } \\
\text { sucked (\%) }\end{array}$ \\
\hline
\end{tabular}




\section{Derived parameters}

Average density of population on a leaf at a given point of time

The average density of population on a leaf at a given point of time $i$ (measured in peaces/leaf):

$$
\rho_{i}=\frac{\sum_{j=1}^{N_{i}} n_{i j}}{N_{i}},
$$

where $n_{i j}$ denotes the number of all entities on the $j^{\text {th }}$ leaf at a given point of time $i$, and $N_{i}$ denotes the number of leaves at a given point of time $i$ (Figs. 1-4).

\section{Accumulating rate at a given point of time}

The accumulating rate of $C$. ciliata at a given point of time $i$ :

$$
\varepsilon_{i}=\frac{R V C_{i}}{R V C_{i}^{\max }},
$$

where $\varepsilon_{i} \in \mathrm{R}, \varepsilon_{i} \geq 1 ; R V C_{i}=\bar{n}_{i} / s_{i}$ denotes the reciprocal of the variation coefficient of $n_{i j}$ for a fixed $i ; R V C_{i}^{\max }$ denotes the reciprocal of the variation coefficient of $n_{i j}$ for a fixed $i$, in case the population is uniformly distributed, that is to say, the maximal possible value of $R V C_{i}$.

In case $\varepsilon_{i}=1$, we say that the population is uniformly distributed. The greatest the number $\varepsilon_{i}$ is, the greatest the rate of grouping is (Figs. 5-6).

\section{Intraspecific association}

The rate of the intraspecific association between the entities of the $k^{\text {th }}$ phenophase and the one before:

$$
a_{i}^{k, k-1}=\frac{\left[P h_{k} P h_{k-1}\right]_{i}^{\exp }}{\left[P h_{k} P h_{k-1}\right]_{i}^{e m p}} \in \boldsymbol{R},
$$

where $k=2,3,4, \mathrm{M}$, or $\mathrm{F}$, which denote the phenophases $2^{\text {nd }}, 3^{\text {rd }}, 4^{\text {th }}$ larval instars, male and female adults, respectively; $\left[P h_{k} P h_{k-1}\right]_{i}^{\exp }$ denotes the expected common appearance of the entities of the $k^{\text {th }}$ and $(k-1)^{\text {th }}$ phenophases; $\left[P h_{k} P h_{k-1}\right]_{i}^{e m p}$ denotes the observed common appearance of the entities of the $k^{\text {th }}$ and $(k-1)^{\text {th }}$ phenophases.

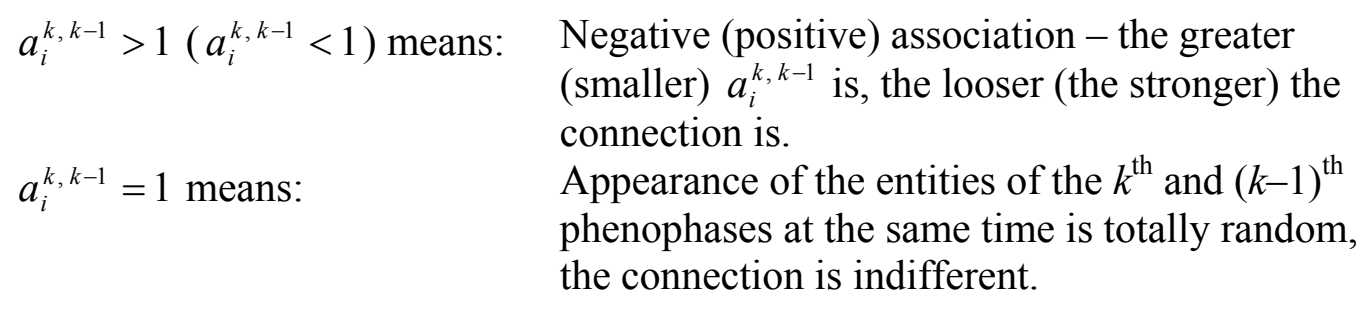


Average biomass at a given point of time

The average biomass at a given point of time $i$ (measured in $\mathrm{mg}$ ):

$$
B_{i}=\sum_{j} n_{i j}^{P h} \cdot M^{P h},
$$

where $n_{i j}^{P h}$ denotes the number of entities of a phenophase $P h$ at a given point of time $i$; $M^{P h}$ denotes the mass of an only entity of a phenophase $P h$ (measured in $m g$ ).

Potential average biomass of the population

The potential average biomass of the population (that is to say, supposed zero percent mortality and migration), at a given point of time $i$ (measured in $m g$ ):

$$
P B_{i}=\sum_{j} \max n_{i j}^{P h} \cdot M^{P h},
$$

where $\sum_{j} \max n_{i j}^{P h}$ denotes the potential number of entities of a phenophase at a given point of time $i$. We calculated $\sum_{j} \max n_{i j}^{P h}$ as follows: we counted the entities of the first phenophase, than we supposed that the mortality and migration \% is zero. Considering the average length of time of a phenophase, we defined the maximal number of the entities of a phenophase at a given point of time $i$.

Limited potential average biomass of the population

The potential average biomass of the population at a given point of time $i$ (measured in $\mathrm{mg}$ ), supposed limited nutrition sources:

$$
\begin{aligned}
L P B_{i} & =\sum_{j} A_{i j}^{r e m} \cdot \rho_{B}^{P h}, \\
A_{i j}^{r e m} & =A_{i j} \quad A_{i j}^{\text {sucked }},
\end{aligned}
$$

where $A_{i j}$ denotes the surface of the $j^{\text {th }}$ leaf at a point of time $i, A_{i j}^{\text {sucked }}$ denotes the sucked surface of the $j^{\text {th }}$ leaf at a point of time $i, \rho_{B M}^{P h}$ denotes the maximum density of biomass (measured in $\mathrm{mg} / \mathrm{cm}^{2}$ ).

The biomass of a single individual of a phenophase $\mathrm{Ph}$

50 pieces of individuals of each phenophase were collected and measured tree times to define the average mass (in $\mathrm{mg}$ ) of a single individual of each phenophase.

\section{Results}

\section{The seasonal dynamics of the diversity of the adults and larvae}

In spring, in the middle of April, after having wintered, the adults moved to the newly developed leaves. They started to suck conditionally. This process was observed at Kodály körönd and at HIRP in 1999, as we started our study on these sites early in spring. 


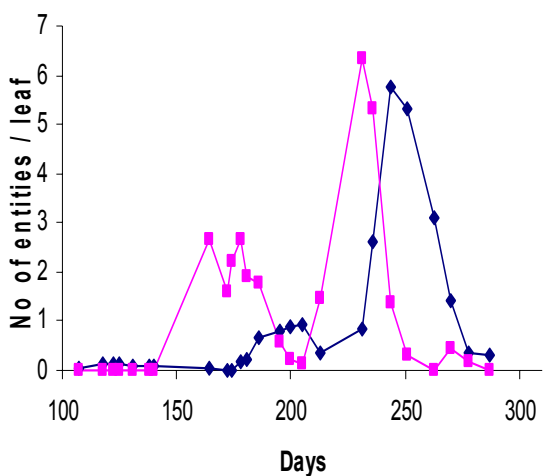

HIRP, 1998

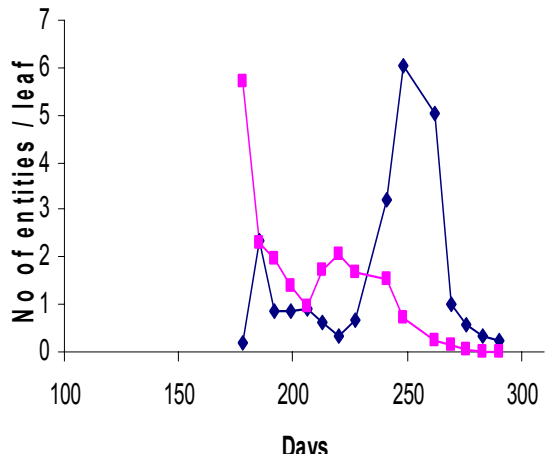

3

Figures 1-4. The average density of population on a leaf at a given point of time $i$ (measured in peaces/leaf)

Larvae of the first generation appeared between middle and end of May and the swarming of the larvae lasted till the end of July. In all the four observations, the first adults appeared at the end of June and they were to be seen till the end of July-the beginning of August.

The individuals of the second generation followed the first adult-generation at the beginning of August, and one could see larvae individuals till October, the time when the adults went to winter.

The density of $C$. ciliata is cyclic in time and the maximal density of the second generation is higher than the one of the first generation. In 1998 and 1999 at ORFI we experienced, that the maximal density of the second adult generation was higher than the one of the first larval generation, which lead to the conclusion of either migration or covering or both.

In order to have a simple view of our recorded data, the average densities of the adults and larvae per leaf are displayed in Figs. 1-4. It can be seen that after the $100^{\text {th }}$ day of the year the wintered individuals appear, and between the $150^{\text {th }}$ and $200^{\text {th }}$ day the larvae of the first generation reach their maximal density. At about the $200^{\text {th }}$ day the adults of the first generation have their maximal density, which is followed by the one of the second larvae-generation, between the $200^{\text {th }}$ and the $250^{\text {th }}$ day. The second adultgeneration culminates at about the $250^{\text {th }}$ day. 
50

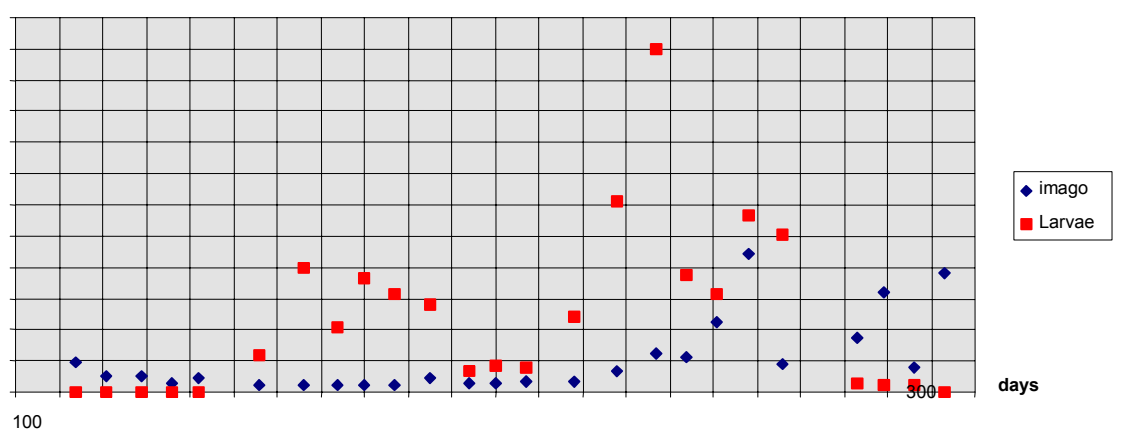

5

$\varepsilon$

Kodály körönd, 1989.

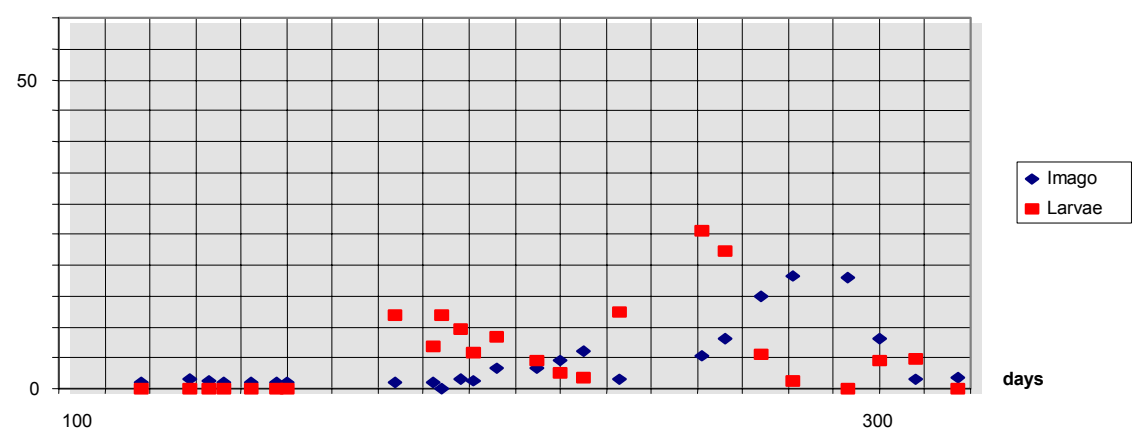

Figures 5-6. The accumulating rate of Corythuch a ciliata at a given point of time $i$

\section{The accumulating rate of Corythucha ciliata at a given point of time $i$}

In Figs. 5 and 6, we can see that the accumulating rates $\varepsilon_{i}$ for adults are lower than for larvae, which means, that the larvae prefer forming groups (Figs. 5, 6). The rate of accumulation, of course, has a similar seasonal pattern to the one of the generations.

\section{The rate of intraspecific association}

Corythucha ciliata prefers forming groups. As $a_{i}^{k, k-1}<1$ for every $i$ and $k$, it can be stated generally, that the entities are associated positive.

The rate of the intraspecific association between the entities of the $k^{\text {th }}$ phenophases and the one before $a_{i}^{k, k-1}$ is growing with $k$. It means that the connection between the states of the first and the second larva phases is quite strong; however, this connection is getting looser and looser as the larva phases are following each other.

The rate of the intraspecific association between the entities of the $k^{\text {th }}$ phenophases and the one before $a_{i}^{k, k-1}$ is growing with the density of population. It means that, for a fixed $\mathrm{k}$, the greater the density of population is, the looser the connection is. Moreover, the value of the rate for adults tends to the number of indifference $\left(a_{i}^{k, k-1}=1\right)$. In case there is enough great number of adults, they are satisfied. If there are a small number of adults, they have to search each other, thus the rate of (positive) association is less (stronger connection). 


\section{The average surface of leaves}

The lengths of the leaves from the bases to the tops were recorded. Moreover, there were 50 peaces of leaves with different kinds of shape collected for our special purpose. Together with the length $\left(l_{i}\right)$ (for $\left.i=1,2, \ldots, 50\right)$, the area $\left(A_{i}\right)$ of each leaf of these 50 was defined with the help of a piece of scale paper. The point pairs $\left(l_{i}, A_{i}\right)$ were displayed in a coordinate system. The functional relation between length and area was approximated by regression (Fig. 13).

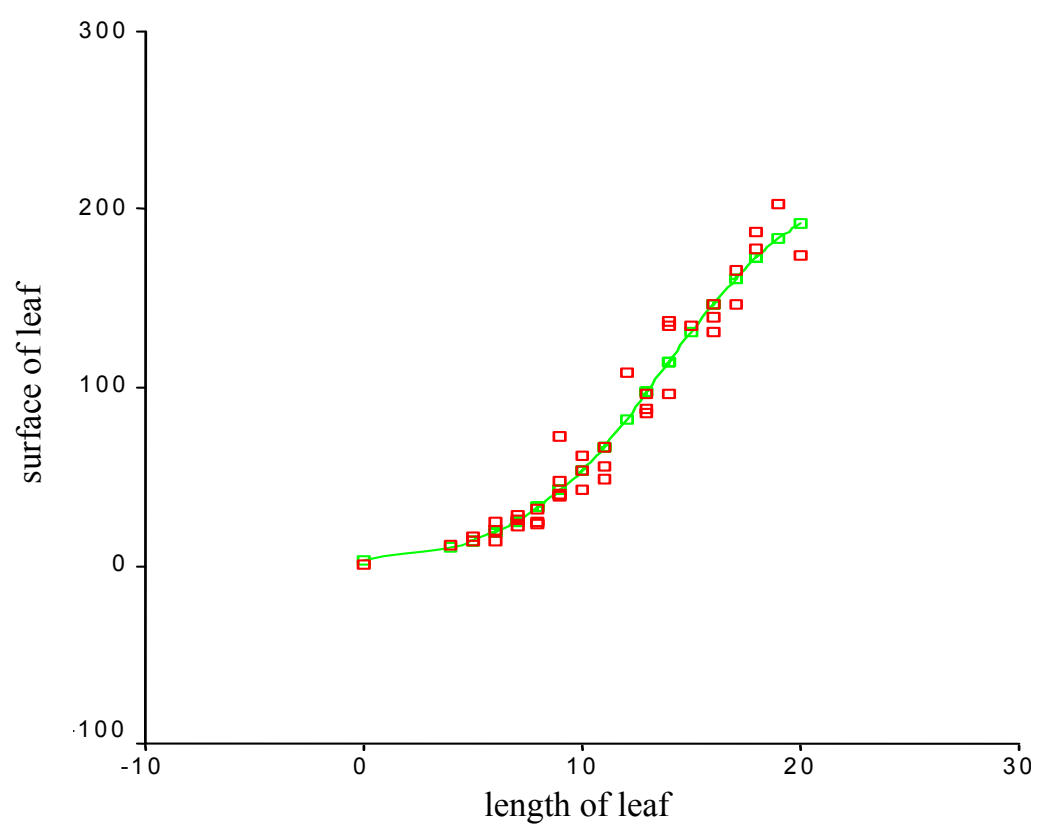

Figure 13 The regression for the average area of leaves depending on the length of the leaf.$\square-=$ logistic fitting, $\square=$ data

Fitting function: $l \mapsto A=\frac{220.8056}{1+\exp (-0.3048(l-13.7431)}$ (correlation coefficient: $\left.R^{2}=0.95915\right)$.

\section{The larvae-adults state plains}

The mortality, together with migration can well be detected in the state plain of larvaeadults. In all the four figures we can see, that the two generations of a vegetation period draw a loop. The smallest the number of the individuals is, the smaller the loop is. 
14
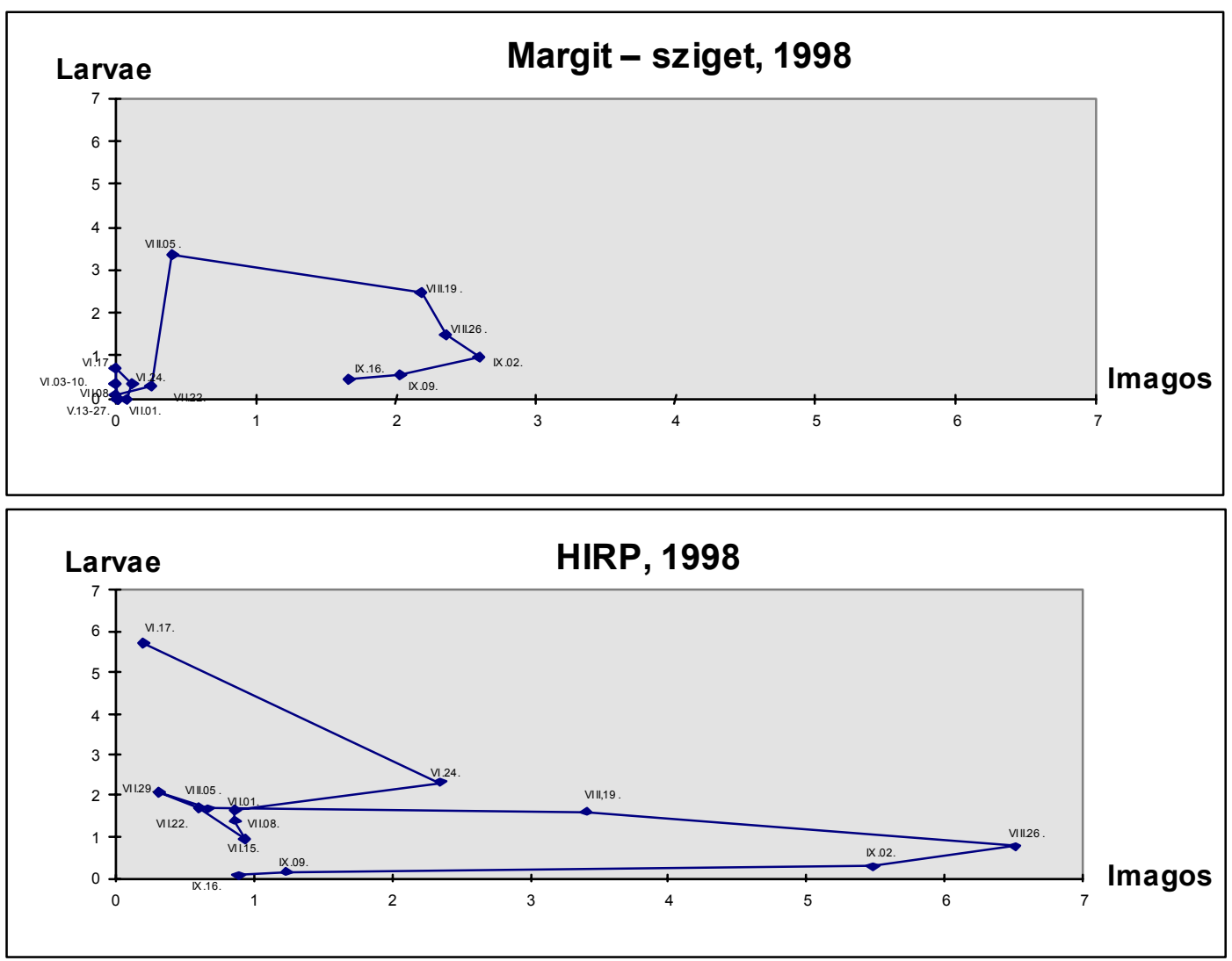

15

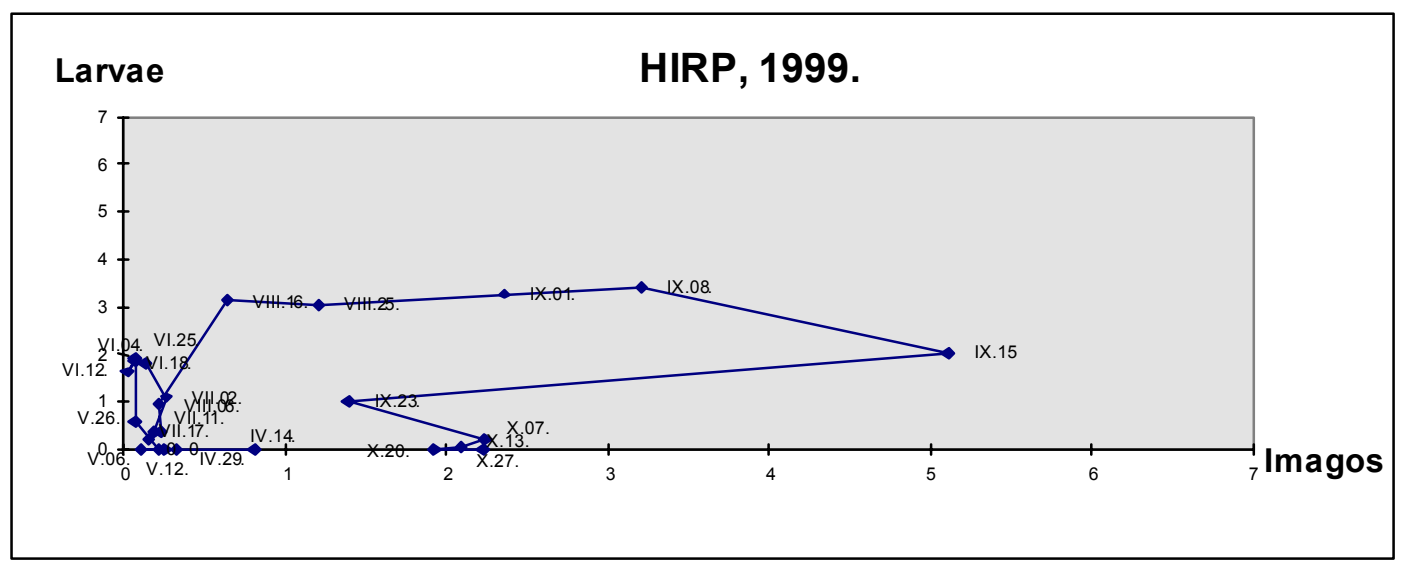

Figures 14-16. The larvae-adults state plains

In Figs. 14-16, it can be observed, that the rate of mortality of the first generation was $20-90 \%$, while the one of the second generation was $10-30 \%$.

\section{A potential biomass model with (LPB) and without limited nutrient source (PB)}

We created a model in order to find out the reasons, why an event or a symptom occurs in the population dynamics. The biomass change in time of the observed population $B_{i}$ was displayed, together with the ones of the two modelled populations $\left(P B_{i}\right.$ and $\left.L P B_{i}\right)$.

It can be seen in both of the figures, that the biomass curve of the observed population $B$ (of $B_{i}$ ) runs under the ones of the potential biomass model $P B$ (of $P B_{i}$ ), and 
the model with limited nutrient source $L P B$ (of $L P B_{i}$ ). In the second half of the vegetation period, the curve of $P B$ crosses the curve of $L P B$.

In case, all the circumstances were ideal for $C$. ciliata, its biomass curve would be identical with the curve $P B$.

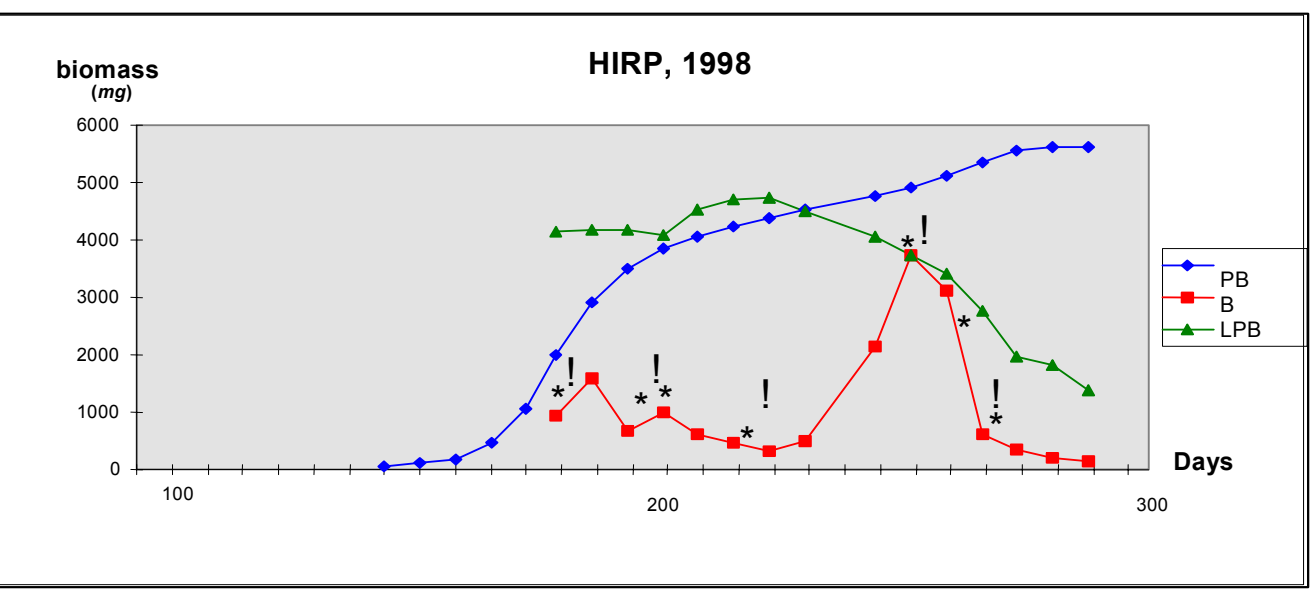

17

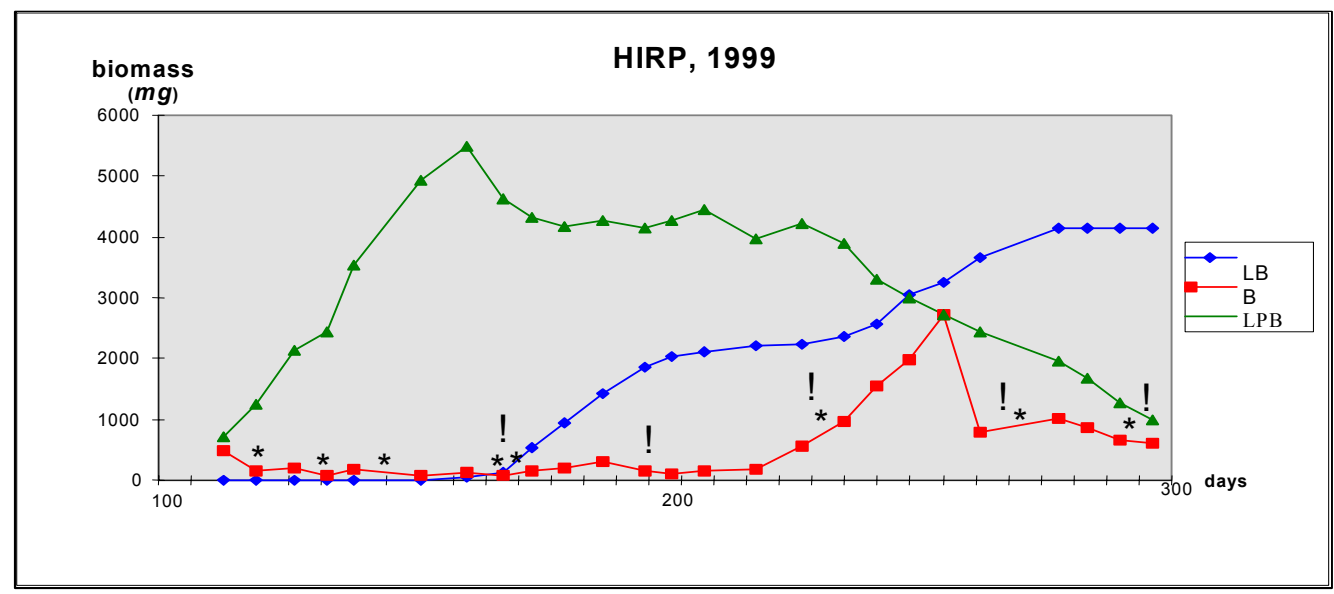

18

Figures 17-18. Seasonal biomass dynamical model

In case, all of the circumstances are ideal for $C$. ciliata, but only nutrient are limited, then, from the common point of $P B$ and $L P B$ on, its biomass curve would be identical with the curve $L P B$. However, we can see that the empirical curve $B$ is much lower than both $P B$ and $L P B$. What is the reason for it?

What are the limiting factors of the reproduction of $C$. ciliata, if it is not the lack of nutrient or the natural enemies (see Review of Literature)? What are the factors that make Corythucha ciliata possible to increase its number of population almost up to its potential maximum?

One of the possible answers can be the effect of weather [17, 22]. The biomass curve was compared with weather extremes; high precipitation events are marked by *, cold fronts are marked with!. 


\section{Discussion}

After having observed four Corythucha ciliata populations, we state the following theses:

1. Corythucha ciliata has two generations in a vegetation period. The density of $C$. ciliata is cyclic in time and the maximal density of the second generation is higher than the one of the first generation.

2. The rate of larvae-adults in the first generation is high, while the one of the second generation is low.

3. Corythucha ciliata individuals, especially the larvae, accumulate spatially. The imagos tend to have more uniform and balanced distribution.

4. The rate of the intraspecific association is positive and its value depends on the actual phenophase; the later the phenophase is, the looser the connection is.

5. The development of C. ciliata is limited not by its biologic potential, but by an other external factor.

6. Living on plane trees, C. ciliata individuals are not food limited, or, if it were so, it happens just at the very end of the vegetation period.

By the reason of the above theseses we set the following hypothesises:

In early spring, the wintered population starts to develop slowly; the environmental circumstances are not favourable even for the first generation. Thus, the mortality is quite high as it was the case in winter, too.

The mortality of the second generation is minimal and, as the imagos can fly, there is a migration to be taken into account. This is supported by fact that on warm September days the air around the trees is full of flying Corythucha ciliata imagos. Their expansion on the tree is due to the mobile imagos that tend to occupy the leaves uniformly. The association between the phenophases is decreasing with time, the larvae are more and more similar to the imagos.

By the biodynamical model we suppose that the population can be limited by food at most in the second half of the vegetation period; the limit factor must be other external factors in the other part of the vegetation. As our investigation, together with other references suggest, the temperature and precipitation have a great role in population dynamics of Corythucha ciliata. Nevertheless, our model needs further investigation.

Planning plant protection treatments, one should take into consideration, that the imagos are going to be distributed uniformly, and so the individuals of the second adultgeneration can fly back to the treated area as it was referred by Cziklin [11]. Our model suggests that the effectiveness of plant protection is less in the second half of the vegetation period. The reason is, the following: food limitation can occur only in this period, thus, because of the intraspecific competition, a less successful plant protection treatment could be favourable for the Corythucha ciliata population. A quite effective protection could be to place a kind of sticky material onto the barks of the trees early in spring, before budding.

\section{Conclusions}

The connection system between meteorological data and seasonal dynamics needs further investigations. A possible way of getting nearer to our aim is, to develop simulation models (like the one in Ladányi et al. [25]), that considers the biomass dynamical aspects, as well as the interactions between the weather and phenology. The 
methods of simulation models have been proved to be very useful and illustrative in the researches of similar ecological problems [16,32]. Similarly to the study of Fahim et al. [14], having several-year field data, we could model the connection between the density and the climatic year types as well.

\section{REFERENCES}

[1] Arzone, A. (1984): Preliminary report on natural enemies of Corythucha ciliata (Say) in Italy. - IUBS Bulletin WPRS IX(1): 34.

[2] Arzone, A. (1984): Spreading and importance of Corythucha ciliata (Say) in Italy twenty years later. - IUBS Bulletin WPRS IX(1):1.

[3] Arzone, A. (1985): Action of pathogenic Deuteromycetes against overwuntering adults of Corythucha ciliata. - IUBS Bulletin WPRS IX(1): 75.

[4] Arzone, A., Ozino-Marletto, OI. (1984): Patogenicita di tre deuteromiceti nei confronti di Corythucha ciliata, Say (Heteroptera, Tingidae). - Redia 1984, 47:195-203.

[5] Balarin, I., Maceljski, M. (1986): Some new results of investigations on the biology and ecology of Corythuca ciliata. II Meeting WG "Integrated Control of C.ciliata" Padova, 1985, Bull. IOBC/WPRS, Bruxelles, IX/1.: 48-52.

[6] Balarin, I., Maceljski, M. (1986): The results of investigations on Corythuca ciliata. I Meeting WG "Integrated Control of C.ciliata", Zagreb, 9-11.10. 1984. Bull. IOBC/WPRS, Bruxelles, IX/1.: 11-19.

[7] Barnard EL, Dixon WN. (1983): Insects and Diseases: Important Problems of Florida's Forest and Shade Tree Resources. Florida Department of Agriculture and Consumer Services, Gainesville, FL. Bulletin No. 196-A. 120 p.

[8] Benedek et al. (1974): Növényvédelmi elörejelzés. Mezőgazdasági Kiadó, Budapest.

[9] Benedek, P. (1985): Short information on Corythucha ciliata in Hungary. IUBS Bulletin WPRS IX(1): 88.

[10] Bürgés, Gy. et al. (1997): A platánfák levélkártevőivel kapcsolatos vizsgálatok és eredmények. Növényvédelem 33(1): 23-27.

[11] Cziklin, M. (1993): Platán-csipkéspoloska (Corythucha ciliata Say.) elterjedésének, kártételének, a védekezés lehetőségének vizsgálata. - Növényvédelem 29(1-2): 52-54.

[12] d'Aguilar R. Pralavorio, Rabasse JM, Mouton R. 1977. Introduction en France du tigre du platane: Corythucha ciliata (Say) (Het. Tingidae). - Bulletin de la Société Entomologique de France 82: 1-6.

[13] Driesche, R.G.V. (1985): Biologycal Control of Corythucha ciliata the Sycamore lace bug, in Europe, trough importation of natural enemies from America: a proprosted project. - IUBS Bulletin WPRS IX(1): 87p.

[14] Fahim, M.A., Hassanien, N.K., Mostafa, M.H. (2003): Relationships between climatic conditions and Potato Late Blight epidemic in Egypt during winter 1999-2001. - Applied Ecology and Environmental Research 1 (1-2): 159-172.

[15] Filer TH, Solomon JD, McCracken FI, Oliveria FL, Lewis R Jr, Weiss MJ, Rogers TJ. 1977. Sycamore Pests: A Guide to Major Insects, Diseases, and Air Pollution. USDA Forest Service, Atlanta, GA. 36 p.

[16] Fodor, N., Kovács, G.J. (2003): Sensitivity of 4M maize model to the inaccuracy of weather and soil input data - Applied Ecology and Environmental Research 1 (1-2):7586.

[17] Hufnagel, L.-Mészáros, Z. (2000): Viszontválasz egy válaszcikk nyomán. Növényvédelem 36(1): 9-11.

[18] Jasinka, J. (1981): Pyrethroidok a platán csipkéspoloska (Corythucha ciliata) elleni küzdelemben. -Növényvédelem 17(7): 302-303.

[19] Jasinka, J., Bozsits, Gy.(1977): A platán csipkéspoloska (Corythucha ciliata) fellépése Magyarországon. -Növényvédelem 13(1): 42-46. 
[20] Kiácz Gy.(ed.) (1967): A fővárosi kertészet 100 éve. - Mezőgazdasági Kiadó, Budapest.

[21] Koletár Cs. (1996): A platánnak nincs párja. - Kertészet és Szőlészet 1996 (1): 20-22.

[22] Kozár F.-Stollár, A. (1990): Klímaváltozást jeleznek a rovarok? - Élet és tudomány 1990 (30): 939-940.

[23] Kükedi, E., Pálmai, O. (1997): Platán-csipkéspoloska (Corythucha ciliata Say) vizsgálatok újabb eredményei és tapasztalatai Martonvásáron. Növényvédelem 33(10): 521-523.

[24] Kükedi, E., Pálmai, O. (1992): A platán-csipkéspoloska (Corythucha ciliata, Say , Heteroptera, Tingidae) megfigyelések eredményei a martonvásári kastélyparkban. Növényvédelem 28(12): 499-503.

[25] Ladányi, M., Horváth, L., Gaál, M., Hufnagel, L. (2003): An agro-ecological simulation model system - Applied Ecology and Environmental Research 1 (1-2): 47-74.

[26] Longo, S. (1985): Remarks on the behaviour of Corythucha ciliata (Say) in Sicily. IUBS Bulletin WPRS IX(1): 53.

[27] Maceljski, M. (1980): La possibilite de lutte biologique du tigre (Corythuca ciliata Say). VI. Journee de phytiatrie et de phytopath., Perpignan: 151-156.

[28] Maceljski, M. (1986): Current status of Corythuca ciliata in Europe. - Europ. Plant Prot. Organ. Conference, Nancy, 1986. Bull. OEPP, 16. : 621-624

[29] Maceljski, M. (1986): New development in the status of Corythuca ciliata in Europe. II. Meeting "Integr. control of C. ciliata", Padova, 1985, Bull. IOBC/WPRS IX/1. Bruxelles.

[30] Maceljski, M. (1986): The appearance of Corythuca ciliata in Europe and the activities to coordinate the research work done on this insect in Europe. I. Meeting "Integr. control of C. ciliata", Zagreb, 1984, Bull. IOBC/WPRS IX/1. Bruxelles.

[31] Maceljski, M., Balarin, I. (1983): An integrated approach to the control of the Sycamore lace bug (Corythuca ciliata, Say). Proc. Intern. Conf. Integr. Plant Prot. Budapest, 4-9.07. 1983.: 119-123.

[32] Máthé-Gáspár, G., Kovács, G.J. (2003): Use of simulation technique to distinguish between the effect of soil and whether on crop development and growth - Applied Ecology and Environmental Research 1 (1-2): 87-92.

[33] Mittempergher, L., Ferrini, F. (1984): La resistenza agli insetti come componente di base della lotta integrata. - La-Difesa-delle-Piante 7 (2): 89-96.

[34] Nikusch, I.W. (1992): Die Platanennetzwanze, Corythucha ciliata Say, und die Rhododendronzikade, Graphocephala coccinea Forster, zwei neuere sich ausbreitende Problemschadlinge fur das Offentliche Grun in Deutschland. Gesunde-Pflanzen, 44 (9): 311-315.

[35] Reiderné Saly, K., Ripka, G. (1990): A platán csipkéspoloska (Corythucha ciliata Say) biológiája és az ellene való védekezés lehetőségei. - Növényvédelem 26(1): 36-40.

[36] Sidor, C. (1985): Micro-organisms pathogenic for Insects till now found in Corythucha ciliata. - IUBS Bulletin WPRS IX(1): 72p.

[37] Soria, S. et al. (1991): Corythucha ciliata (Say, 1832) (Heteroptera: Tingidae) en la Comunidad de Madrid. Boletin-de-Sanidad-Vegetal-Plagas 17( 3): 440.

[38] Tavella, L., Arzone, A. (1987): Indagini sui limitatori naturali di Corythucha ciliata (Say) (Rhynchota, Heteroptera). - Redia 70: 443-457.

[39] Tóth J. (1997): Behurcolt és új erdészeti kártevők Magyarországon. - Erdészeti lapok 132 (10): $327-328$.

[40] Török, K., Botta-Dukát, Z., Dancza, I., Németh, I., Kiss J., Mihály, B., Magyar, D. (2003): Invasion Gateways and Corridors in the Carpathian Basin: Biological Invasions in Hungary - Biological Invasions, 5(4): 349-356.

[41] Tremblay, E. (1985): Evaluation of the different possibilities of chemical control. - IUBS Bulletin WPRS IX(1): 68.

[42] Vásárhelyi, T., Hufnagel, L. (1990): A platánfa légies átka. - Élet és tudomány 1990(30): 940-942. 
[43] Wicki, C. (1984): Trials againts Corythucha ciliata in Basel. - IUBS Bulletin WPRS IX(1): 37.

[44] Wulf, A., Butin, H. (1987): Krankheiten und Schadlinge der Platane. - Nachrichtenblattdes-Deutschen-Pflzenschutzdienstes 39(10): 145-148.

[45] Zangheri, S. (1984): Syntheses des observations sur la biologie de la Corythucha ciliata.IUBS Bulletin WPRS IX(1):20.49-356(8) 